\title{
CARBON STOCK AND RESPIRATION OF RHIZOSPHERE SOILS OF SAL (SHOREA ROBUSTA ROXB. EX. GAERTN. F.) IN RELATION TO SOME ENVIRONMENTAL VARIABLES OF DIFFERENT SAL FOREST STANDS OF BANGLADESH
}

\author{
Maliha Jerin Propa, Mo Imran Hossain ${ }^{1}$ and Ashfaque Ahmed* \\ Ecology, Environment and Natural Resource laboratory, Department of Botany, \\ University of Dhaka, Dhaka-1000, Bangladesh
}

Keywords: Climate change, Carbon stock, Soil respiration, Sal forest, Acidic soil

\begin{abstract}
Effects of some environmental variables (moisture, temperature, $\mathrm{pH}$ ) on the carbon stock and respiration in the rhizosphere soil of Sal (Shorea robusta Roxb. ex. Gaertn. f.) of 11 different Sal forest stands situated in Cumilla, Gazipur, Sherpur, Modhupur, Dinajpur and Rangpur of Bangladesh were assessed. Soil samples were collected from two layers (upper layer, $0-15 \mathrm{~cm}$ and lower layer, $15-30 \mathrm{~cm}$ depth). During February 2019, samples were collected from Kotbari and Rajeshpur of Cumilla and during June 2019, samples were collected from the rest of the stands. The values of different variables showed fluctuations, e.g. moisture content $(11.87-38.78 \%)$, $\mathrm{pH}(4.73$ to 6.03$)$, conductivity $(63.13-248.83 \mu \mathrm{S} / \mathrm{cm})$, soil organic carbon (135.43 - $1263.53 \mathrm{ton} / \mathrm{ha})$ and respiration $\left(75.95-91.8 \mathrm{mg} \mathrm{CO}_{2} / \mathrm{g}\right.$ soil) respectively. Rates of respiration increased where $\mathrm{pH}$ remained 4 to 6 and the temperature 20 to $34^{\circ} \mathrm{C}$. Rate of respiration also increased when the amount of moisture content and carbon stock decreased. This research will help to understand the role of environmental factors on the variability of soil C dynamics in the natural Sal forest areas of Bangladesh.
\end{abstract}

\section{Introduction}

Soil carbon stock and respiration play an important role in the global carbon cycle, and about $50-75 \%$ of the total respiration occurs in the terrestrial ecosystems (Zhou et al. 2012). The soil pool from which soil respiration releases carbon is almost four times greater than the atmospheric pool, so a small change in soil respiration can seriously alter the $\mathrm{CO}_{2}$ concentration balance (Martín Rubio and Rodríguez 2017). Therefore, soil respiration has to be well studied for predicting changes in the carbon cycle (Lou and Zhou 2006). Soil respiration refers the production of $\mathrm{CO}_{2}$ by the biological activity of soil organisms, including plant roots, microbes and soil animals (Martín Rubio and Rodríguez 2017). $\mathrm{CO}_{2}$ is produced through several processes such as root respiration, rhizosphere respiration, the decomposition of dead plant material and oxidation of organic matter (Lou and Zhou 2006). Besides, several environmental factors (temperature, moisture, nitrogen content and $\mathrm{pH}$ of the soil) are responsible for soil respiration (Martín Rubio and Rodríguez 2017). Moisture has been expressed gravimetrically as a percentage of moisture content, such as water holding capacity or oven dry weight of soil (Orchard and Cook 1983). Soil respiration rates are highly sensitive to temperature and may show a large response to climate changes (Townsend et al. 1992). $\mathrm{pH}$ is important for the growth of soil microbes and soil respiration (Martín Rubio and Rodríguez 2017). Soil respiration is an important process for the flow of carbon in forest ecosystems. Large amount of carbon are released to the atmosphere as $\mathrm{CO}_{2}$ during decomposition of litter and $\mathrm{CO}_{2}$ is also released by the respiration of living roots (Bowden et al. 1993). Little change in soil respiration occurred if the carbon stored in the soil is

*Author for correspondence: <aashfaque67.bot@du.ac.bd>. 'Department of Chemistry, University of Dhaka, Dhaka-1000, Bangladesh. 
changed, but these small changes and shifts in plant carbon allocation determine ecosystem carbon storage and its exchange in the atmosphere (Ryan and Law 2005). Soil respiration is important because it is a good indicator of soil quality and soil fertility (Haney et al. 2008). Because of its major role in carbon loss from ecosystems, soil respiration has received much attention and the number of studies of soil respiration has been increased (Ryan and Law 2005, Martín Rubio and Rodríguez 2017). Despite its importance in the current global climate change scenario, no substantial data are available on the dependency of soil respiration on moisture, temperature, $\mathrm{pH}$ and carbon input in the Sal forests, one of the major forest types of Bangladesh. Thus the present study aimed to focus on the effects of moisture, temperature and $\mathrm{pH}$ on soil carbon stock and respiration and the amount of $\mathrm{CO}_{2}$ respired by soil microorganisms of natural Sal forests of Bangladesh.

\section{Materials and Methods}

Naturally grown Sal forests in Cumilla, Gazipur, Sherpur, Modhupur, Dinajpur and Rangpur were selected for soil sampling from the rhizosphere of Sal trees. Twelve soil samples were collected from two layers (upper layer, $0-15 \mathrm{~cm}$ and lower layer, $15-30 \mathrm{~cm}$ depth) from each sampling sites (Table 1) by following the method of Wu et al. (2016).

Table 1. Different locations of Sal forests from where the samples were collected.

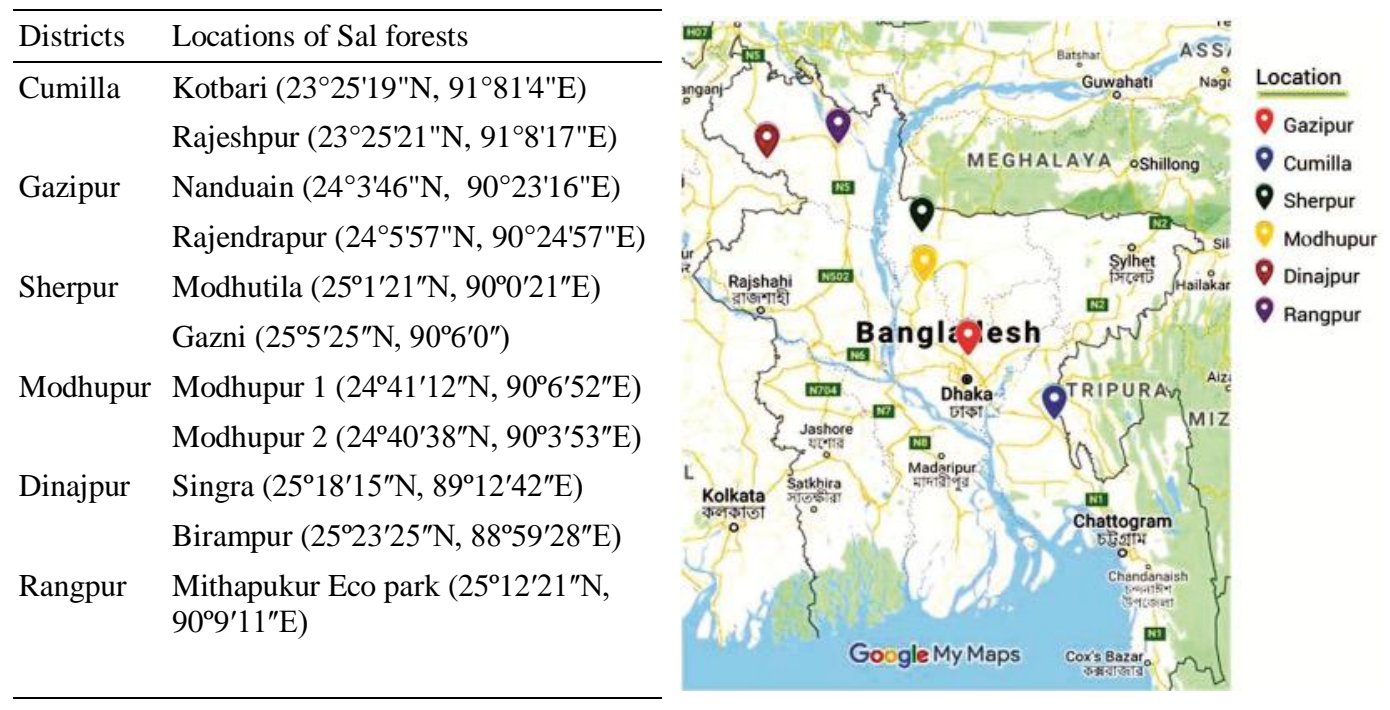

For the determination of soil moisture content, $10 \mathrm{~g}$ fresh soil was taken into a cup made with aluminium foil and then kept in an oven at $104^{\circ} \mathrm{C}$ temperatures for $24 \mathrm{hrs}$. Soil moisture content was determined by the following formula:

Soil moisture content $(\%)=\frac{F-D}{F} \times 100$

where, $\quad \mathrm{F}=$ Weight of fresh soil $(10 \mathrm{~g})$ and $\mathrm{D}=$ Weight of dry soil.

Soil $\mathrm{pH}$ and conductivity were recorded in the laboratory within $24 \mathrm{hrs}$ after collection from the field. Soil $\mathrm{pH}$ and soil conductivity were determined in suspension with distilled water $(1: 2.5$, w:v) and (1:5, w: v), respectively. The $20 \mathrm{~g}$ soil was taken in a beaker and then $50 \mathrm{ml}$ distilled 
water was added for measuring $\mathrm{pH}$ and $100 \mathrm{ml}$ distilled water for measuring conductivity to make a suspension by shaking well. The suspension was kept for a while for settling down of the particles. The $\mathrm{pH}$ meter (Hanna $\mathrm{pH}$ meter, $\mathrm{pHeP}$ ) was calibrated with known $\mathrm{pH}(6.76)$ and the conductivity meter (Aqua Lytic CD 22) was calibrated with known conductivity. Then, the $\mathrm{pH}$ and conductivity values were recorded in triplicate for the soil samples.

Organic carbon of the soil was determined by Walkley and Black method (Walkley and Black 1934). For determination of organic carbon, the following formula was used

where,

$$
\% \text { of organic carbon }=\frac{(\mathrm{B}-\mathrm{T}) \times 0.003 \times 1.3 \times 100}{\mathrm{~W}}
$$

$\mathrm{B}=$ Amount in $\mathrm{ml}$ of $\mathrm{N} \mathrm{FeSO}_{4}$ solution required in this experiment (for blank)

$\mathrm{T}=$ Amount in $\mathrm{ml}$ of $\mathrm{N} \mathrm{FeSO}_{4}$ solution required in experiment with soil

$\mathrm{W}=$ Weights of soil taken

For determination of soil OM following formula was used.

$$
\% \text { of total } \mathrm{OM}=\% \text { of organic carbon } \times 1.72 \text { (Van Bemmelen factor) }
$$

Bulk density was calculated by following the methods described by Sahu et al. (2016).

Finally, SOC was estimated using the following formula as described by Donato et al. (2011) and Sahu et al.(2016) and the amounts were converted into tonnes per hectare.

SOC $=$ Bulk density $\left(\mathrm{g} / \mathrm{cm}^{3}\right) \times$ soil depth $(\mathrm{cm}) \times$ organic carbon $(\%)$

Through measuring the rate of $\mathrm{CO}_{2}$ evolution, the rate of soil respiration (Rs) was determined. The rate of $\mathrm{CO}_{2}$ evolution was determined by the conversion to $\mathrm{CO}_{3}{ }^{-}$in the presence of excess $\mathrm{OH}^{-}$ In this reaction excess $\mathrm{OH}^{-}$was consumed, so that if the initial and final amounts of $\mathrm{OH}^{-}$were known by chemical titration, the amount of $\mathrm{CO}_{2}$ were calculated. Chemical titration for measuring soil $\mathrm{CO}_{2}$ respiration is an effective and easy method among three methods for measuring soil respiration. Definite amount of soils were taken into mason jars along with an aqueous solution of $\mathrm{KOH}$ or $\mathrm{NaOH}$ in a small vial. The alkali $(\mathrm{KOH}$ or $\mathrm{NaOH})$ reacts chemically with $\mathrm{CO}_{2}$. Then definite amount of $\mathrm{BaCl}_{2}$ was added in the vial and centrifuged it for a definite time, then supernatant of the mixture along with distilled water and phenolphthalein indicator the mixture was titrated with $\mathrm{HCl}$ and the end point was relative to the amount of $\mathrm{CO}_{2}$ released by soil microorganisms. An equation is then employed to arrive at $\mathrm{mg} \mathrm{CO}_{2}$ per g soil (Haney et al. 2008, Martin Rubio and Rodríguez 2017).

Soils of 11 different Sal forest stands were analysed in the study. To compare the amount of $\%$ moisture, $\mathrm{pH}$, conductivity, $\mathrm{OM}, \mathrm{SOC}$ and Rs between the locations, upper and lower layers, descriptive statistics and one-way ANOVA was performed using Minitab 14 software. Means \pm standard deviation was also presented.

\section{Results and Discussion}

Soil variables such as moisture, $\mathrm{pH}$, conductivity, $\mathrm{OM}, \mathrm{SOC}$ and Rs were determined and the data are presented in Table 2. Highly significant differences $(\mathrm{P}=0.001)$ were found in moisture, pH, conductivity, OM, SOC and Rs between Kotbari and Rajeshpur location (Table 2). In Kotbari and Rajeshpur (Cumilla) the amount of moisture content was found to range from 11.87 to 21.05 $\%$ (Table 2). The values of $\mathrm{pH}$ and conductivity ranged from $4.8 \pm 0$ to $4.9 \pm 0.3$ and $140.17 \pm 2.47$ to $176.67 \pm 35.11 \mu \mathrm{s} / \mathrm{cm}$ (Table 2). The amount of OM and SOC ranged from 0.92 to $2.06 \%$ and 
$445.24 \pm 177.13$ to $1134.73 \pm 200.70$ ton/ha, respectively (Table 2). Rate of Rs ranged from 82.55 \pm 0.57 to $91.8 \pm 0.40 \mathrm{mg} \mathrm{CO}_{2} / \mathrm{g}$ soil (Table 2). Ahmed et al. (2015) reported that in Kotbari and Rajeshpur location during May and December the value of moisture content was $18.53 \%$, $\mathrm{pH}$ was 4.60 to 5.37 , conductivity was 10.08 to $27.03 \mu \mathrm{S} / \mathrm{cm}$ and $\mathrm{OM}$ was 0.345 to $3.362 \%$.

Highly significant differences $(\mathrm{P}=0.001)$ were found in moisture, $\mathrm{pH}$, conductivity, $\mathrm{OM}, \mathrm{SOC}$ and Rs between Nanduain and Rajendrapur locations (Table 2), It might be due to the fact that the number of tree were more in the Nanduain area than that of Rajeshpur area. In Nanduain and Rajendrapur (Gazipur) the amount of moisture contents ranged from 29.8 to $34.03 \%$ (Table 2). The values of $\mathrm{pH}$ and conductivity ranged from $4.73 \pm 0.06$ to $5.57 \pm 0.06$ and $125.17 \pm 17.10$ to $243.67 \pm 43.48 \mu \mathrm{s} / \mathrm{cm}$, respectively (Table 2). The amount of OM and SOC ranged from 0.78 to $1.44 \%$ and $772.53 \pm 387.81$ to $1041.24 \pm 291.63$ ton/ha, respectively (Table 2). Rate of Rs was found to range from $76.4 \pm 0.83$ to $78.55 \pm 2.84 \mathrm{mg} \mathrm{CO}_{2} / \mathrm{g}$ soil (Table 2). The present results are in agreement with the results reported earlier by Yousuf et al. (2001) who found the moisture content with a range of $2.99-16.01 \%$ in Chandra Sal forest, Gazipur district. They found the $\mathrm{pH}$ 4.4 and maximum value of conductivity was $161.45 \mu \mathrm{S} / \mathrm{cm}$ in Mouchak during April and June.

Highly significant differences $(\mathrm{P}=0.001)$ were found in moisture, $\mathrm{pH}$, conductivity, $\mathrm{OM}, \mathrm{SOC}$ and Rs between Modhutila and Gazni location (Table 2). In Modhutila and Gazni (Sherpur) the amount of moisture content ranged from 26.03to $28.47 \%$ (Table 2). The values of $\mathrm{pH}$ and conductivity were found to range from $5.13 \pm 0.21$ to $5.68 \pm 0.32$ and $63.13 \pm 10.26$ to $99.5 \pm 3$ $\mu \mathrm{s} / \mathrm{cm}$, respectively (Table 2). The amount of OM and SOC ranged from 0.64 to $0.93 \%$ and 535.19 \pm 138.83 to $824.31 \pm 358.10$ ton/ha, respectively (Table 2 ). Rate of Rs ranged from $75.95 \pm 1.00$ to $84.05 \pm 3.03 \mathrm{mg} \mathrm{CO} / \mathrm{g}$ soil (Table 2 ).

No significant differences were found in $\mathrm{pH}$ and less significant differences $(\mathrm{P}=0.05)$ were found in Rs but highly significant differences $(\mathrm{P}=0.001)$ were found in moisture, conductivity, $\mathrm{OM}$ and SOC between two locations of Modhupur (Table 2). In Modhupur the amount of moisture content ranged from 35.30 to $38.78 \%$ (Table 2). The values of $\mathrm{pH}$ and conductivity ranged from $5.4 \pm 0$ to $5.43 \pm 0.12$ and $108.33 \pm 44.15$ to $173.67 \pm 66.13 \mu \mathrm{s} / \mathrm{cm}$, respectively (Table 2 ). The amount of OM and SOC ranged from 0.62 to $1.26 \%$ and $541.47 \pm 200.70$ to $1263.53 \pm 375.30$ ton/ha, respectively (Table 2). Rate of Rs ranged from $78.75 \pm 1.37$ to $79.65 \pm 0.91 \mathrm{mg} \mathrm{CO} / \mathrm{g}_{2}$ soil (Table 2). Hoque et al. (2008) noted the moisture content of $23.82 \%$ and $\mathrm{pH}$ less than 6 for every two months in Modhupur Sal forest.

Significant differences $(\mathrm{P}=0.05)$ were found in moisture, $\mathrm{pH}$ but highly significant differences $(\mathrm{P}=0.001)$ were found for conductivity, OM, SOC and Rs between Singra and Birampur locations (Table 2). In Singra and Birampur (Dinajpur) the amount of moisture contents ranged from 32.07 to $34.39 \%$ (Table 2). The values of $\mathrm{pH}$ and conductivity ranged from $5.63 \pm 0.29$ to $5.88 \pm 0.22$ and $77.88 \pm 15.94$ to $97.63 \pm 14.86 \mu \mathrm{s} / \mathrm{cm}$, respectively (Table 2 ). The amount of OM and SOC ranged from 0.14 to $0.74 \%$ and $135.43 \pm 98.53$ to $536.86 \pm 228.75$ ton/ha (Table 2). Rate of Rs ranged from $77.9 \pm 3.13$ to $81 \pm 2.33 \mathrm{mg} \mathrm{CO} / \mathrm{g}$ soil (Table 2).

In Rangpur at Mithapukur Ecopark the mean amount of moisture content, $\mathrm{pH}$, conductivity, $\mathrm{OM}$, SOC and soil respiration were found to $33.54,5.98 \pm 0.07,78.44 \pm 4.51 \mu \mathrm{s} / \mathrm{cm}, 0.42 \%$, $348.84 \pm 33.74$ ton/ha and $82.13 \pm 0.46 \mathrm{mg} \mathrm{CO}_{2} / \mathrm{g}$ soil, respectively (Table 2). In Nepal, Dhital et al. (2019) reported that soil respiration averaged value was $357 \mathrm{mg} \mathrm{CO}_{2} \mathrm{~m}^{-2} / \mathrm{h}$ in October 2015, and in April 2016 it was $444.6 \mathrm{mg} \mathrm{CO} \mathrm{m}^{-2} / \mathrm{h}$. In Iran, Bakhshandeh et al. (2019) found $206.71 \pm$ 34.44 to $730.84 \pm 81.69 \mathrm{mg} \mathrm{CO}_{2}-\mathrm{C} / \mathrm{kg}$ soil of cumulative respiration (CumR) in 1, 2, 4, 28 days. In Spain, Martín Rubio and Rodríguez (2017) reported that the value of soil respiration was 26.22 to $62.86 \mathrm{mmol} \mathrm{CO} / \mathrm{Kg}$. Barba et al. (2016) found annual soil respiration from July 2012 to July 2013 was $2.6 \pm 0.6 \mu \mathrm{mol} \mathrm{m} \mathrm{m}^{-2}$, heterotrophic respiration was $1.7 \pm 0.3 \mu \mathrm{mol} \mathrm{m} \mathrm{m}^{-2}$ while 


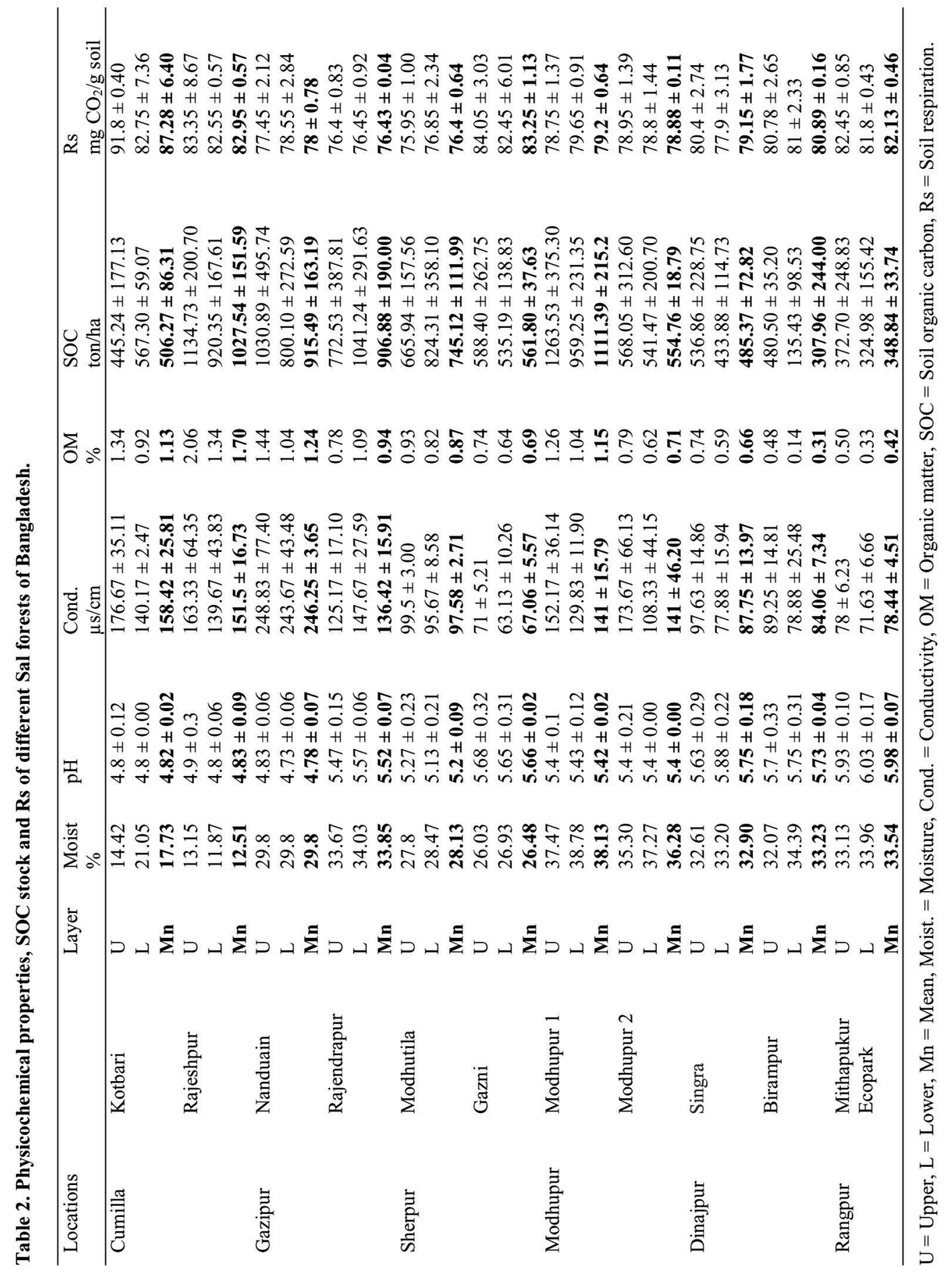




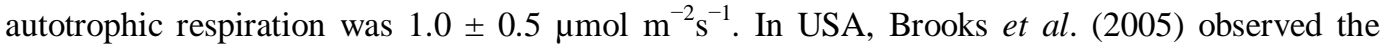
lowest fluxes were associated with a coniferous forest (soil carbon $7.8 \% ; \mathrm{CO}_{2}$ flux $212 \pm 37 \mathrm{mg} \mathrm{C}$ $\mathrm{m}^{2} /$ day) and the highest fluxes associated with a deciduous forest (soil carbon $22.2 \% ; \mathrm{CO}_{2}$ flux $386 \pm 40 \mathrm{mg} \mathrm{C} \mathrm{m} /$ day) and they reported mean daily $\mathrm{CO}_{2}$ flux rates between January and May ranged from 212 to $386 \mathrm{mg} \mathrm{C} \mathrm{m}^{2} /$ day. The observation of higher rate of $\mathrm{Rs}$ in the present study might be due to the fact that it is a broad leaved deciduous forest.

It was interesting to note that in most of the cases in the upper and lower layers of different soil samples in different locations, where the amount of SOC was higher, the rate of Rs was lower (Fig. 1). Relationship between SOC and Rs was done through Sigma plot software (10) and presented in (Fig. 1).

In Cumilla at Kotbari in the upper layer the value of SOC was lower but the rate of Rs was higher (Fig. 1a). Soil respiration is a good indicator of ecosystem metabolism but a poor indicator of changes in ecosystem carbon storage (Ryan and Law 2005). At Rajeshpur in the upper layer the value of SOC was higher but the rate of Rs was lower (Fig. 1a). Highly significant differences were found in SOC and Rs between Kotbari and Rajeshpur (Fig. 1a). But no significant differences were found in SOC and Rs between these two Sal stands because in the lower layer the value of SOC and the rate of Rs was almost same (Fig. 1b).

In Nanduain (Gazipur), the upper layer value of SOC was higher but the rate of Rs was lower (Fig. 1a). At Rajendrapur, the upper layer value of SOC was lower but the rate of Rs was higher (Fig. 1a). But in the lower layer opposite relation was found (Fig. 1b). Highly significant differences $(\mathrm{P}=0.001)$ were found in SOC and Rs between these two Sal stands for both upper and lower layer (Fig. 1a).

In Modhutila (Sherpur), the value of SOC was higher both in the upper and lower layer but the rate of Rs was lower (Fig. 1c, d). At Gazni both in the upper and lower layer the value of SOC was lower but the rate of Rs was higher (Fig. 1c, d). Highly significant differences $(p=0.001)$ were found for both upper and lower layer in SOC and Rs between Modhutila and Gazni (Fig. 1c, d).

In one location of Modhupur in the upper layer the value of SOC was higher but the rate of Rs was lower (Fig. 1c). At another location of Modhupur $\left(24^{\circ} 40^{\prime} 38^{\prime \prime} \mathrm{N}, 90^{\circ} 3^{\prime} 53^{\prime \prime} \mathrm{E}\right)$ opposite trend was found i.e. in the upper layer the value of SOC was lower but the rate of Rs was higher (Fig. 1c). Highly significant differences $(\mathrm{p}=0.001)$ were found in SOC and soil respiration between two stands of Modhupur Sal forest (Fig. 1c). In the lower layer, the value of SOC was higher and the rate of Rs was lower for two locations of Modhupur (Fig. 1d).

At Singra in Dinajpur both in the upper and lower layers the value of SOC was higher but the rate of Rs was lower (Fig. 1e, f). At Birampur, in both the upper and lower layers, the value of SOC was lower but the rate of Rs was higher (Fig. 1e, f). Significant differences $(\mathrm{P}=0.05)$ were found in SOC and Rs between Singra and Birampur (Fig. 1e, f).

In Rangpur at Mithapukur Ecopark in the upper layer the value of SOC was lower but the rate of Rs was higher and in the lower layer the value of SOC was higher but the rate of Rs was lower (Fig. 1e, f). Highly significant differences $(\mathrm{P}=0.001)$ were found in $\mathrm{SOC}$ but significant differences were found in soil respiration between upper and lower layer of these place.

Moisture content, $\mathrm{pH}$ and SOC has great impact on Rs. In most of the cases the rate of Rs increases when the amount of moisture content, $\mathrm{pH}$ and SOC decreases. Effects of moisture, $\mathrm{pH}$ and SOC on Rs was done through Sigma plot software (10) and shown in (Fig. 2).

In the upper layer of different Sal forest stands by arranging the value of Rs in ascending order are Gazipur > Modhupur $>$ Sherpur $>$ Dinajpur $>$ Rangpur $>$ Cumilla (Fig. 2a) 
(a)

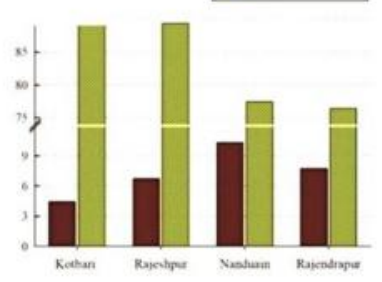

(b)

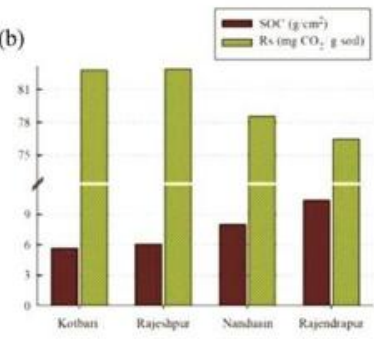

(c)
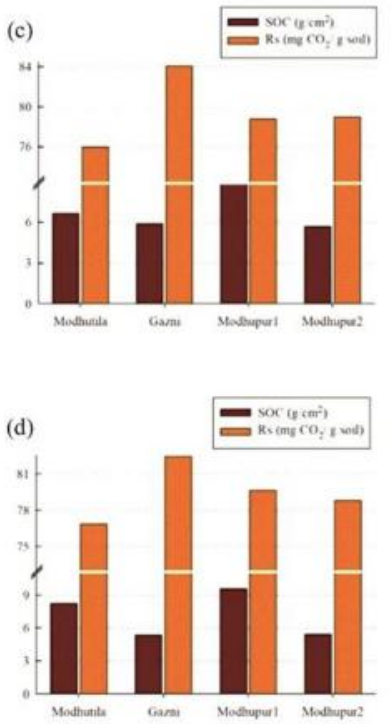

(e)
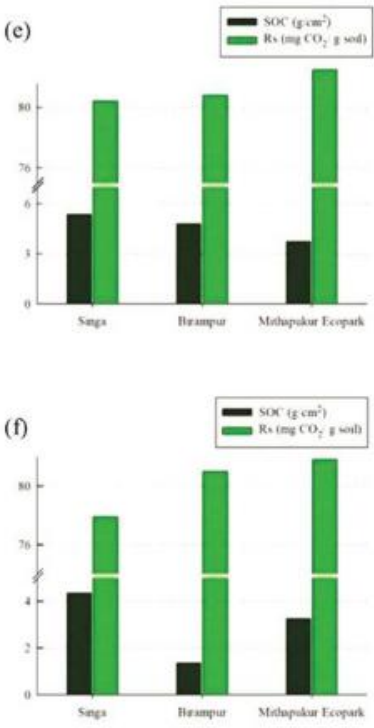

Fig. 1. Relationship between SOC and Rs in the (a, c, e) upper (0-15 cm) and (b, d, f) lower (16-30 cm) layer of different Sal forests.

In Cumilla both for upper and lower layers, the rates of Rs were higher when $\mathrm{pH}$ and moisture content were lower than the rest forest stands (Fig. 2a, b). Soil respiration decreases as temperature increases (Janssens and Pilegaard 2003, Price and Sowers 2004). In other places except Cumilla rate of Rs increases when $\mathrm{pH}$ increases but in most of the cases rate of Rs increases when moisture content and SOC decreases (Fig. 2a).

In dry condition, soil respiration occurs at a very little amount. Rate of Rs increases after rainfall but during raining time the rate of respiration decreases (Lou and Zhou 2006). High moisture content might be responsible for the lower rate of respiration at Modhupur because it was raining during field sample collection. Zhou et al. (2012) mentioned that when the soil is too dry or too wet, the soil respiration is inhibited.

In the lower layer of different Sal forest stands by arranging the value of Rs in ascending order are Gazipur > Modhupur > Dinajpur > Sherpur > Rangpur > Cumilla (Fig. 2b). In most cases both in the upper and lower layer, the rate of Rs was higher the rate of moisture content and SOC was lower there. So, it can be said that, Rs increases if moisture content and SOC decreases (Fig. 2a, b).

In the study, the values of $\mathrm{pH}$ found to range from 4.7 to 6.0. Production of $\mathrm{CO}_{2}$ increased at $\mathrm{pH}$ more than 3 and less than 7. So, soil respiration increases within $\mathrm{pH} 4$ to 6 (Lou and Zhou 2006). Respiration in a clear-cut forest may be dominated by SOM decomposition, with only a small contribution by root respiration (Bowden et al. 1993). The higher rate of respiration might be due to having more amount of SOM. Soil respiration is a good indicator of ecosystem metabolism but a poor indicator of changes in ecosystem carbon storage (Ryan and Law 2005). It could be the reason that where SOC is higher the rate of respiration is lower. Santini et al. (2019) found that Soil respiration was significantly higher in the top soil $(0-10 \mathrm{~cm})$ compared to the deeper soil $(20-30 \mathrm{~cm})$ regardless of habitat. In the present study in most of the cases it was found that the rate of respiration was higher in the upper layer $(0-15 \mathrm{~cm})$ than in the lower layer $(15-30 \mathrm{~cm})$. 

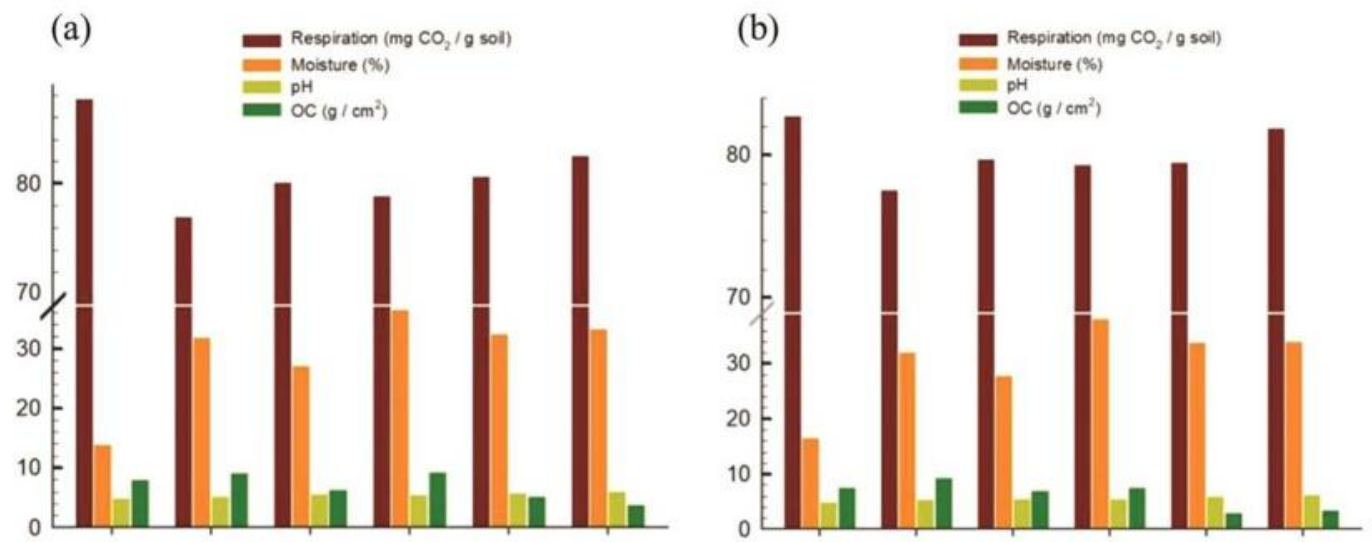

Fig. 2. Effects of moisture, $\mathrm{pH}$ and SOC on Rs in the (a) upper layer and (b) lower layer of different Sal forests of Bangladesh.

It could be concluded that soils of the studied Sal forests were moderate to highly acidic in nature. The value of SOC for different Sal stands are less than 1. So soil organic carbon status indicated that soils of Sal forests were nutritionally poor. Higher Rs resulted in lower amount of SOC. Soil respiration occurred in different Sal forests of Bangladesh indicating that the forest acts as source as well as sink of $\mathrm{CO}_{2}$.

\section{Acknowledgement}

The corresponding author gratefully acknowledge the financial support received from Special Allocation (2018-2019) of Ministry of Science and Technology, Government of the People's Republic of Bangladesh.

\section{References}

Ahmed A, Akber MM, Rahman MO and Chaudhury MMR 2015. Effects of management practice on the community structure and species diversity of Sal (Shorea robusta Gaertn.) forest at Comilla. J. Biodivers. Conserv. Bioresour. Manag. 1(2): 73-82.

Bakhshandeh E, Francaviglia R, and Renzi G 2019. A cost and time-effective method to evaluate soil microbial respiration for soil quality assessment. Appl. Soil Ecol. 140: 121-125.

Barba J, Yuste CJ, Poyatos R, Janssens IA, and Lloret F 2016. Strong resilience of soil respiration components to drought-induced die-off resulting in forest secondary succession. Oecol. 182(1): 27-41.

Bowden RD, Nadelhoffer KJ, Boone RD, Melillo JM and Garrison JB 1993. Contributions of aboveground litter, belowground litter, and root respiration to total soil respiration in a temperate mixed hardwood forest. Can. J. For. Res. 23(7): 1402-1407.

Brooks PD, McKnight D and Elder K 2005. Carbon limitation of soil respiration under winter snowpacks: potential feedbacks between growing season and winter carbon fluxes. Global Change Biol. 11(2): 231238.

Dhital D, Prajapati S, Maharjan SR, Koizumi H 2019. Soil carbon dioxide emission: soil respiration measurement in temperate grassland, Nepal. J. Environ. Protec. 10(2): 289-314.

Donato DC, Kauffman JB, Murdiyarso D, Kurnianto S, Stidham M and Kanninen M 2011. Mangroves among the most carbon-rich forests in the tropics. Nature Geosci. 4(5): 293. 
Haney RL, Brinton WF and Evans E 2008. Soil $\mathrm{CO}_{2}$ respiration: Comparison of chemical titration, $\mathrm{CO}_{2}$ IRGA analysis and the Solvita gel system. Renew. Agric. Food Syst. 23(2):171-176.

Hoque AE, Nazrul-Islam AK and Huq SM 2008. Seasonal variation of edaphic features of Madhupur Sal forest, Bangladesh. Ecoprint 15: 7-14.

Janssens IA and Pilegaard KI 2003. Large seasonal changes in $\mathrm{Q}_{10}$ of soil respiration in a beech forest. Glob. Change Biol. 9(6): 911-8.

Luo Y and Zhou X 2006. Soil respiration and the environment. Amsterdam; Boston: Elsevier Academic Press. ISBN 10: 0-12-088782-7.

Martín Rubio L and Rodríguez SB 2017. Carbon Dioxide Titration Method for Soil Respiration Measurements. Universidad De Valladolid, Spain, pp. 66.

Orchard VA and Cook FJ 1983. Relationship between soil respiration and soil moisture. Soil Biol and Biochem. 15(4): 447-53.

Price PB and Sowers T 2004. Temperature dependence of metabolic rates for microbial growth, maintenance, and survival. Proc. Nat. Acad. Sci. 101(13): 4631-6.

Ryan MG and Law BE 2005. Interpreting, measuring, and modeling soil respiration. Biogeochem. 73(1): 327.

Sahu SC, Kumar M and Ravindranath NH 2016. Carbon stocks in natural and planted mangrove forests of Mahanadi Mangrove Wetland, East Coast of India. Curr. Sci. (00113891). 110(12).

Santini NS, Lovelock CE, Hua Q, Zawadzki A, Mazumder D, Mercer TR, Muñoz-Rojas M, Hardwick SA, Madala BS, Cornwell W and Thomas T 2019. Natural and regenerated saltmarshes Exhibit Similar Soil and Belowground Organic Carbon Stocks, Root Production and Soil Respiration. Ecosyst.1-20.

Townsend, AR, Vitousek PM and Holland EA 1992. Tropical soils could dominate the short-term carbon cycle feedbacks to increased global temperatures. Clim. Change 22: 293-303.

Walkley A and Black IA 1934. An examination of the Degtjareff method for determining soil organic matter, and a proposed modification of the chromic acid titration method. Soil Sci. 37(1): 29-38.

Wu P, Xiang X, Xu Z, Lu C, Cheng H, Lyu X, Zhang J, He W, Deng W, Lyu Y, Lou Q and Hong Y 2016. Bacterial communities in rhizospheres of three mangrove tree species from Beilun estuary, China.

Yousuf M, Nazrul-Islum AKM, Samsad SZKM and Ahmed A 2001. Ecological conditions of Chandra deciduous forest. Ecoprint 8(1): 95-97.

Zhou JX, Cui M and Yin L 2012. Characteristics of Soil Respiration and its Environmental Factors of Poplar Plantation on Beach Land of the Yangtze River. Procedia Environ. Sci. 13:18-29. 